\title{
IMPROVED OF THE EXPERIMENTING SKILL BY GUIDED INQUIRY LEARNING MODEL ON SCIENCE LEARNING
}

\author{
Universitas Sebelas Maret \\ nandasari162@gmail.com
}

Nanda Sari Rizki, Kartono, Hadiyah

\section{Article History}

accepted 09/07/2018

approved 01/08/2018

published 17/09/2018

\section{Keywords}

experimenting skill, science learning, guided inquiry learning model.

\begin{abstract}
This reseach is a Classroom Action Research that purpose to improve the experimenting skill by using Guided Inquiry learning model in grade $V$ studens of Elementary School of academic year 2017/2018. This research conducted in three cycles. Each cycles consist of 2 meeting and includes four component: preparation, action, observation and reflection. Data analysis technique used data collection, data reduction, data presentation and conclution. Data collecting technique used observation, interviews, and documentation. Data validity technique used triangulation source and triangulation technique. Based on the result of the research, it can know that Guided Inquiry model has improved of average score of student's experimenting skill in cycle I, cycle II and cycle III. In the Precycle average score 41,3 (0\%). After used Guided Inquiry model at the meeting 2 of first cycle the average increased to 48,1 (0\%). In the meeting 2 of second cycle the average increased to 58,0 (8,33\%), In the meeting 2 of third cycle the average increased to 79,5 (83,33\%). Based on this research, it can be concluded that the application of Guided Inquiry model can improve the skill of experimenting.
\end{abstract}

Social, Humanities, and Education Studies (SHEs): Conference Series https://jurnal.uns.ac.id/shes

p-ISSN 2620-9284 e-ISSN 2620-9292 


\section{PENDAHULUAN}

IImu Pengetahuan Alam atau yang sering disingkat dengan IPA merupakan mata pelajaran penting dan harus ada pada sekolah terutama pada sekolah tingkat dasar. IPA merupakan suatu ilmu membahas segala sesuatu yang berkenaan dengan alam. Dengan adanya mata pelajaran IPA, siswa diharapkan dapat mengenal dan mempelajari diri sendiri dan alam sekitar dengan baik. Samatowa (2009: 1) menjelaskan bahwa IPA bagian disiplin ilmu physical sciences dan life sciences. IPA adalah ilmu yang berkaitan dengan gejala alam dan kebendaan yang tersusun secara teratur dan sistematis, berlaku umum dan merupakan kumpulan dari hasil suatu observasi dan eksperimen. Dalam pembelajaran IPA perlu adanya kegiatan observasi, eksperimen, penyimpulan masalah, penyusunan teori dari suatu fakta, konsep dan prinsip yang ada. Tidak hanya pengetahuan saja yang diperlukan, namun juga diperlukan sikap ilmiah dan keterampilan berproses agar bisa mengungkap dan memahami segala sesuatu yang berkenaan dengan alam.Keterampilan berproses dalam IPA disebut dengan keterampilan proses sains. Tujuan dari adanya keterampilan proses sains adalah untuk menyelesaikan atau memecahkan suatu permasalahan. Seperti yang dikemukakan (Aktamis \& Ergin, 2008) dalam Zeidan \& Jayosi (2015) bahwa keterampilan proses sains merupakan alat untuk menghasilkan dan menggunakan ilmu pengetahuan dan digunakan untuk penelitian ilmiah dan untuk menyelesaikan suatu masalah.

Terdapat beberapa keterampilan proses sains yang perlu dimiliki dan dikembangkan oleh siswa agar dapat mengembangkan kemampuan berpikirnya dan keterampilannya, yaitu: 1) observasi, 2) klasifikasi 3) aplikasi, 4) prediksi, 5) interpretasi, 6) menggunakan alat, 7) eksperimen, 8) komunikasi, 9) mengajukan pertanyaan. Salah satu keterampilan berproses yang harus ditingkatkanoleh siswa untuk lebih memahami suatu konsep adalah keterampilan berekperimen. Dengan adanya keterampilan bereksperimen siswa dapat belajar menemukan dan memahami suatu konsep ataupun teori yang ada pada mata pelajaran IPA, dan dengan melakukan eksperimen maka hasilnya akan berkesan yang lama dan tidak mudah dilupakan.

Menurut Gagne dalam Majid (2014:50) terdapat sembilan kategori peristiwa mengajar yang dibutuhkan untuk meningkatkan transfer pengetahuan dan persepsi, salah satunya adalah membangun kinerja. Hal ini berkaitan dengan bisa atau tidaknya siswa dalam melakukan keterampilan yang telah mereka pelajari dari suatu inforamsi yang didapatkan agar transfer ilmu yang didapat semakin meningkat. UNESCO telah menetapkan empat pilar pendidikan yang perlu diperhatikan dalam pendidikan yaitu : (1) learning to know, (2) learning to do, (3) learning to live together, (4) learning to be, (Hamdani, 2014: 194).

Salah satu kompetensi pembelajaran IPA di sekolah dasar yaitu siswa perlu mengadakan pengamatan objek IPA dengan mengarahkan semua panca indra yang dimiliki dengan menggunakan alat dan bahan sederhana. Kegiatan pembelajaran itu terpaparkan pada kegiatan eksperimen. Dengan kegiatan eksperimen siswa dengan leluasa mengeksplorasi kemampuan yang dimilikinya dengan menggunakan semua panca indra serta peralatan sederhana untuk membuktikan atau menemukan suatu konsep atau fakta. Sekolah dan guru hendaknya memfasilitasi untuk mengaktaktualisasikan keterampilan siswa yaitu dengan cara menciptakan suatu pembelajaran yang aktif, menumbuhkan rasa kreatif siswa, yang mampu menarik minat siswa dengan kegiatan yang menyenangkan, menumbuhkan rasa keingintahuan siswa dengan menggunakan model pembelajaran yang menarik yang mampu menggugah minat dan perhatian siswa yang nantinya mampu meningkatkan 
keterampilan siswa terutama dalam pembelajaran IPA yaitu keterampilan bereksperimen. Pada kenyataannya pada kelas V Sekolah Dasar jarang melakukan kegiatan eksperimen, dan sebagian besar siswa tidak paham dengan kegiatan bereksperimen. Hal ini dibuktikan hasil pratindakan dari keterampilan bereksperimen yang dilakukan pada siswa kelas V SD Negeri Reksosari 01 Kecamatan Suruh, Kabupaten Semarang pada tanggal 23 Desember 2017 yang menyimpulkan bahwa siswa yang mendapatkan nilai keterampilan bereksperimen di bawah kriteria ketuntasan minimal yang telah ditentukan yaitu $(<75)$ sebanyak 24 siswa yang diuraikan 16 siswa $(66,66 \%)$ yang termasuk kategori cukup terampil, 6 siswa $(25 \%)$ dalam kategori kurang terampil dan 2 siswa $(8,3 \%)$ termasuk kategori tidak terampil. Sedangkan siswa yang nilainya mencapai KKM $(\geq 75)$ tidak ada. Berdasarkan hasil tersebut dapat diketahui bahwa keterampilan bereksperimen kelas V SD Negeri Reksosari 01 memperoleh hasil yang rendah.

Dalam mata pelajaran IPA terutama dalam kegiatan bereksperimen pada sekolah dasar perlu dilaksanakan dengan suatu model pembelajaran yang mampu menggerakkan siswa untuk mengeksporasi keterampilan dan mampu mempermudah siswa untuk memahami suatu konsep atau fakta yang ada. Model pembelajaran yang tepat dalam peningkatan keterampilan bereskperimen dalam mata pelajaran IPA salah satunya adalah dengan model pembelajaran Guided Inquiry (Inkuiri Terbimbing).

Pembelajaran inkuiri mampu mengembangkan daya pikir siswa. Hal ini seperti yang dikemukakan Fathurrohman (2015: 104) bahwa tujuan model pembelajaran inkuiri untuk mengajak siswa dalam mengembangkan intelektual terkait pada proses berpikir yang reflektif. Hal ini juga didukung dengan pendapat Sund dalam Fathurrohman (2015: 104) yang menjelaskan bahwa dalam inkuiri terdapat proses mental seperti merumuskan masalah, merancang eksperimen, melaksanakan eksperimen, mengumpulkan data, menganalisis dan membuat kesimpulan. Model ini cocok digunakan dalam mata pelajaran IPA untuk meningkatkan keterampilan siswa dalam melakukan eksperimen atau percobaan untuk membuktikan suatu konsep atau fakta. Dalam inkuiri melatih siswa untuk mengajukan pertanyaan dan memecahkan permasalahan dengan melalui serangkaian kegiatan mulai dari kegiatan mengamati hingga mengkomunikan hasil pengamatan. Hal ini sependapat dengan National Science Teacher Association dalam Wenning (2011: 3) bahwa:

Scientific inquiry is a powerful way of understanding science content. Student learn how to ask question and use evidence to answer them. In the process of learning the strategies scientific inquiry, student learn to conduct an investigation and collect evidence from a variety of sources, develop an explanation from the data, and communicate and defend their conclusions

Pernyataan tersebut dapat dijelaskan bahwa model pembelajaran inkuiri merupakan cara ampuh untuk memahami konten sains. Siswa belajar bagaimana mengajukan pertanyaan dan menggunakan bukti untuk menjawabnya. Dalam proses belajar Inquiry, siswa belajar untuk melakukan penyelidikan dan mengumpulkan bukti dari berbagai sumber, mengembangkan penjelasan dari data, dan mengkomunikasikan dan mempertahankan kesimpulan mereka. Kelebihan atau keuntungan menggunakan model pembelajaran Guided Inquiry yaitu: 1) Model pembelajaran Guided Inquiry menggugah semangat siswa dalam belajar; 2) Model pembelajaran Guided Inquiry memberikan kesempatan siswa untuk lebih mandiri dalam belajar sesuai dengan cara maupun gaya belajar siswa sendiri sesuai dengan kemampuan mereka untuk melakukan suatu penemuan sendiri dengan tetap ada arahan dan pengawasan dari guru namun tetap dengan batasa-batasannya; 3) Model pembelajaran Guided Inquiry 
melatih siswa menjadi kreatif seperti seorang ilmuan; 4) Model pembelajaran Guided Inquiry melatih untuk lebih aktif dalam mengikuti kegiatan pembelajaran; 5) Model pembelajaran Guided Inquiry membuat pembelajaran lebih menyenangkan dan akan terasa bermakna.

Pelaksanaan proses pembelajaran model Guided Inquiry guru tidak lepas tangan, namun tetap membimbing serta mengarahkan siswa dalam melakukan kegiatan, guru juga harus bisa mengawasi agar siswa yang berpikir lambat tetap dapat mengikuti proses pembelajaran dan siswa yang cerdas tidak menguasai jalannya pembelajaran. Model pembelajaran Guided Inquiry adalah proses siswa menjawab pertanyaan dan memecahkan suatu masalah dengan jalan suatu pengujian fakta atau konsep, jadi pada proses pembelajaran menggunakan model ini siswa diajak untuk mempelajari suatu konsep mulai dari perumusan masalah, perumusan hipotesis dan membuat hipotesis serta menguji hipotesis itu sendiri serta membuat kesimpulan atas penelitian yang telah dilakukan. Dengan langkah-langkah tersebut diharapkan selain mengembangkan kognitif dan afektif dalam pembelajarannya, dengan model pembelajaran ini siswa bisa mengembangkan ranah psikomotornya yaitu pada keterampilan bereksperimen. Hal ini didukung dengan pendapat Hardiansah (2017) yang mengemukakan bahwa dimensi proses sangat memegang peranan penting dalam menunjang proses perkembangan peserta didik secara utuh, karena dapat melibatkan aspek kognitif, afektif dan psikomotor.

Berdasarkan penjelasan di atas peneliti melaksanakan suatu Penelitian Tindakan Kelas (PTK) dengan judul "Peningkatan Keterampilan Bereksperimen dengan Model Pembelajaran Guided Inquiry pada Mata Pelajaran IPA (Penelitian Tindakan Kelas pada Siswa Kelas V Sekolah Dasar Tahun Ajaran 2017/2018)".

\section{METODE}

Penelitian ini dilaksanakan di kelas V SD Negeri Reksosari 01 Kecamatan Suruh Kabupaten Semaranag pada semester II Tahun Ajaran 2017/2018 pada bulan Desember sampai bulan April 2018. Subjek penelitian adalah guru dan siswa kelas V yang berjumlah 24 siswa terdiri 11 siswa laki-laki dan 13 siswa perempuan. Prosedur penelitian ini dilakukan melalui empat tahapan yaitu perencanaan, pelaksanaan tindakan, observasi, dan melakukan refleksi. Teknik pengumpulan data menggunakan teknik wawancara, observasi, dokumentasi. Teknik analisis data menggunakan model analisis interaktif yang terdiri dari empat komponen berupa pengumpulan data, reduksi data, penyajian data, dan penarikan kesimpulan. Validitas data menggunakan triangulasi sumber data dan triangulasi teknik.

\section{HASIL DAN PEMBAHASAN}

Pada kondisi awal, keterampilan bereksperimen siswa masih rendah atau memperoleh nilai dibawah kategori terampil $\geq 75$. Hal ini dibuktikan dengan hasil observasi pratindakan yaitu dari 24 siswa tidak ada siswa yang memperoleh nilai $\geq 75$ atau masuk kategori terampil. Sebanyak 6 siswa dalam kategori cukupterampil,16 siswa dalam kategori kurang terampil dan 2 siswa masuk kategori tidak terampil. Distribusi nilai keterampilan bereksperimen pada pratindakan dapat dilihat pada tabel 1 berikut: 
Tabel 1. Distribusi Frekuensi Nilai Keterampilan Bereksperimen Pratindakan

\begin{tabular}{|c|c|c|c|c|}
\hline \multirow{2}{*}{$\begin{array}{c}\text { interval } \\
\text { nilai }\end{array}$} & \multirow[t]{2}{*}{$f$} & \multirow[t]{2}{*}{ median } & \multicolumn{2}{|c|}{ (\%) } \\
\hline & & & Relatif & kumulatif \\
\hline $20,8-27,8$ & 3 & 24,3 & 12,5 & 12,5 \\
\hline $28,8-35,8$ & 6 & 32,3 & 25 & 37,5 \\
\hline $36,8-43,8$ & 5 & 40,3 & 20,83 & 58,3 \\
\hline $44,8-51,8$ & 7 & 48,3 & 29,16 & 87,5 \\
\hline $52,8-59,8$ & 0 & 56,3 & 0 & 87,5 \\
\hline $60,8-67,8$ & 3 & 64,3 & 12,5 & 100 \\
\hline Jumlah & 24 & & 100 & \\
\hline Nilai rata-rata & & & 41.3 & \\
\hline Ketuntasan Klasika & & & $0 \%$ & \\
\hline Nilai di bawah KKM & & & $100 \%$ & \\
\hline Nilai Tertinggi & & & 66,7 & \\
\hline Nilai Terendah & & & 20,8 & \\
\hline
\end{tabular}

Pada data Tabel 1. menunjukkan bahwa nilai keterampilan bereksperimen pada kegiatan pratindakan pada siswa kelas V SD Negeri Reksosaari 01 mendapatkan nilai tertinggi 66,7 dan nilai terendah yaitu 20,8 . Untuk nilai rata-rata kelas yaitu 41.3 dengan siswa yang mendapatkan nilai dibawah KKM sebesar $100 \%$ dan ketuntasan klasikal sebesar $0 \%$.

Nilai keterampilan bereksperimen siswa pada siklus I mengalami peningkatandan dapat dilihat dari jumlah siswa yang sudah memenuhi indikator kinerjasudah me-ningkat. Pada siklus I diperoleh nilai terendah adalah 29,2 sedangkan nilai tertinggi adalah 70,8. Distribusi frekuensi nilai keterampilan bereksperimen pada siklus I pertemuan 1 dapat dilihat pada Tabel 2. di bawah ini:

Tabel 2. Distribusi Frekuensi Nilai Keterampilan Bereksperimen Siklus I Pertemuan 1

\begin{tabular}{|c|c|c|c|c|}
\hline \multirow{2}{*}{$\begin{array}{c}\text { interval } \\
\text { nilai }\end{array}$} & \multirow[t]{2}{*}{$f$} & \multirow[t]{2}{*}{ median } & \multicolumn{2}{|c|}{ (\%) } \\
\hline & & & Relatif & kumulatif \\
\hline $29,5-35,5$ & 4 & 33 & 16,67 & 16,67 \\
\hline $36,5-42,5$ & 5 & 40 & 20,83 & 37,50 \\
\hline $43,5-49,5$ & 2 & 47 & 29,16 & 66,67 \\
\hline $50,5-56,5$ & 7 & 54 & 8,33 & 75,00 \\
\hline $57,5-63,5$ & 3 & 61 & 12,5 & 87,50 \\
\hline $64,5-70,5$ & 3 & 68 & 12.5 & 100 \\
\hline Jumlah & 24 & & 100 & \\
\hline Nilai rata-rate & & & 48.1 & \\
\hline Ketuntasan & & & $0 \%$ & \\
\hline Nilai di bawa & & & $100 \%$ & \\
\hline Nilai Tertings & & & 70,8 & \\
\hline Nilai Terenda & & & 29,2 & \\
\hline
\end{tabular}

Berdasarkan Tabel 2. diketahui bahwa belum ada yang memperoleh nilai KKM ysng telah ditentukan. Sebanyak 13 siswa atau 54,17\% masuk kategori cukup terampil 
dan Sebanyak 11 siswa atau 45,83\% masuk kategori kurang terampil. Pada pertemuan 2 nilai keterampilan bereksperimen mengalami peningkatan. Nilai terendah pada pertemuan 2 adalah 45,8 dan nilai tertinggi sebesar 75. Distribusi frekuensi nilai keterampilan bereksperimen pada siklus I pertemuan 2 dapat dilihat pada Tabel 3. di bawah ini:

Tabel 3. Distribusi Frekuaensi Nilai Keterampilan Bereksperimen Siklus I Pertemuan 2

\begin{tabular}{|c|c|c|c|c|}
\hline \multirow{2}{*}{$\begin{array}{c}\text { Interval } \\
\text { Nilai }\end{array}$} & \multirow[t]{2}{*}{$f$} & \multirow[t]{2}{*}{ Median } & \multicolumn{2}{|c|}{ (\%) } \\
\hline & & & Relatif & kumulatif \\
\hline $46-50$ & 7 & 48 & 29.167 & 29,17 \\
\hline $51-55$ & 5 & 53 & 20.83 & 50 \\
\hline $56-60$ & 2 & 58 & 8.33 & 58,3 \\
\hline $61-65$ & 6 & 63 & 25 & 83,3 \\
\hline $66-70$ & 1 & 68 & 4.17 & 87,5 \\
\hline $71-75$ & 3 & 73 & 12.5 & 100 \\
\hline Jumlah & 24 & & 100 & \\
\hline Nilai rata-ra & & & 58,0 & \\
\hline Ketuntasan & & & $8,33 \%$ & \\
\hline Nilai di baw & & & $91,66 \%$ & \\
\hline Nilai Tertin & & & 75 & \\
\hline Nilai Teren & & & 45,8 & \\
\hline
\end{tabular}

Berdasarkan Tabel 3. diketahui bahwa 2 siswa yang memperoleh nilai KKM dan masuk ketegori terampil atau sebanyak 8,33\%. Sebanyak 20 siswa atau $83,33 \%$ masuk kategori cukup terampil dan Sebanyak 2 siswa atau 8,33\% masuk kategori kurang terampil. Berdasarkan siklus I pertemuan 2, indikator kinerja belum tercapai yaitu $80 \%$ tetapi mengalami peningkatan dibandingkan dengan pertemuan 1 dan harus dilanjutkan pada siklus 2. Adapun nilai siklus II pertemuan 1 dapat dilihat pada tabel 4 berikut:

Tabel 4. Distribusi Frekuensi Nilai Keterampilan Bereksperimen Siklus II Pertemuan 1

\begin{tabular}{|c|c|c|c|c|}
\hline \multirow{2}{*}{$\begin{array}{c}\text { interval } \\
\text { nilai }\end{array}$} & \multirow[t]{2}{*}{$f$} & \multirow[t]{2}{*}{ median } & \multicolumn{2}{|c|}{ (\%) } \\
\hline & & & Relatif & Kumulatif \\
\hline $50-54$ & 3 & 33 & 12,5 & 12,5 \\
\hline $55-59$ & 4 & 40 & 16,7 & 29,17 \\
\hline $60-64$ & 5 & 47 & 20,83 & 50 \\
\hline $65-69$ & 3 & 54 & 12,5 & 62,5 \\
\hline $70-74$ & 6 & 61 & 25 & 87,5 \\
\hline $\begin{array}{l}75-79 \\
\text { Jumlah }\end{array}$ & $\begin{array}{r}3 \\
24\end{array}$ & 68 & $\begin{array}{l}12,5 \\
100\end{array}$ & 100 \\
\hline Nilai rata-ra & & & 64,9 & \\
\hline Ketuntasan & & & $12,5 \%$ & \\
\hline Nilai di baw & & & $87,5 \%$ & \\
\hline Nilai Terting & & & 79,2 & \\
\hline Nilai Terenc & & & 50,0 & \\
\hline
\end{tabular}


Berdasarkan Tabel 4. diketahui bahwa 3 siswa yang memperoleh nilai KKM yang telah ditentukan dan berarti masuk pada kategori terampil atau $12,5 \%$. Sebanyak 21 siswa atau 87,5\% masuk kategori cukup terampil. Nilai tertinggi 79,2 dan nilai terendah sebesar 50,0. Untuk siklus II pertemuan 2 juga mengalami peningkatan yaitu perolehan nilai teryinggi sebesar 83,3 dan terendah 54,2 . Kemudian untukdistribusi nilai siklus II pertemuan dapat dilihat pada Tabel 5 berikut ini:

Tabel 5. Distribusi Frekuensi Nilai Keterampilan Bereksperimen pada siklus II Pertemuan 2

\begin{tabular}{|c|c|c|c|c|}
\hline \multirow{2}{*}{$\begin{array}{c}\text { Interval } \\
\text { Nilai }\end{array}$} & \multirow[t]{2}{*}{$f$} & \multirow[t]{2}{*}{ Median } & \multicolumn{2}{|c|}{ (\%) } \\
\hline & & & Relatif & kumulatif \\
\hline $54-58$ & 4 & 56 & 16,67 & 16,67 \\
\hline $59-63$ & 3 & 61 & 12,5 & 29,17 \\
\hline $64-68$ & 4 & 66 & 16,67 & 45,83 \\
\hline $69-73$ & 5 & 71 & 20,83 & 66.67 \\
\hline $74-78$ & 5 & 76 & 20,83 & 87,5 \\
\hline $79-83$ & 3 & 81 & 12,5 & 100 \\
\hline Jumlah & 24 & & 100 & \\
\hline Nilai rata-ra & & & 68.9 & \\
\hline Ketuntasan & & & $33,33 \%$ & \\
\hline Nilai di baw & & & $66,67 \%$ & \\
\hline Nilai Terting & & & 83,3 & \\
\hline Nilai Tereno & & & 54,2 & \\
\hline
\end{tabular}

Berdasarkan Tabel 5 diketahui bahwa 8 siswa yang memperoleh nilai KKM yang telah ditentukan dan berarti masuk pada kategori terampil atau 33,33\%. Sebanyak 16 siswa atau 66,67\% masuk kategori cukup terampil. Berdasarkan siklus II pertemuan 2 belum mencapai indikator kinerja yaitu $80 \%$, maka dilanjutkan pada siklus III. Untuk nilai siklus III pertemuan 1 dapat dilihat pada distribusi nilai pada Tabel 6.

Tabel 6. Distribusi Frekuensi Nilai Keterampilan Bereksperimen pada siklus III Pertemuan 1

\begin{tabular}{|c|c|c|c|c|}
\hline \multirow{2}{*}{$\begin{array}{c}\text { interval } \\
\text { nilai }\end{array}$} & \multirow[t]{2}{*}{$f$} & \multirow[t]{2}{*}{ Median } & \multicolumn{2}{|c|}{ (\%) } \\
\hline & & & Relatif & kumulatif \\
\hline $62,5-66,5$ & 5 & 64,5 & 20,83 & 20,83 \\
\hline $67,5-71,5$ & 6 & 69,5 & 25 & 45,83 \\
\hline $72,5-76,5$ & 4 & 74,5 & 16,67 & 62,5 \\
\hline $77,5-81,5$ & 3 & 79,5 & 12,5 & 75 \\
\hline $82,5-86,5$ & 4 & 84,5 & 16.67 & 91,67 \\
\hline $\begin{array}{l}87,5-91,5 \\
\text { Jumlah }\end{array}$ & $\begin{array}{r}2 \\
24\end{array}$ & 89,5 & $\begin{array}{r}8.33 \\
100\end{array}$ & 100 \\
\hline Nilai rata-rata & & & 74,7 & \\
\hline Ketuntasan Klasikal & & & $54,17 \%$ & \\
\hline Nilai di bawah KKM & & & $45,83 \%$ & \\
\hline Nilai Tertinggi & & & 91,7 & \\
\hline Nilai Terendah & & & 62,5 & \\
\hline
\end{tabular}


Berdasarkan Tabel 6 dapat dilihat terjadi peningkatan perolehan nilai, nilai tertinggi sebesar 91,7 dan nilai terendah 62,5. diketahui bahwa 13 siswa yang memperoleh nilai KKM yang telah ditentukan dan berarti masuk pada kategori terampil atau 54,17\%. Sebanyak 11 siswa atau 45,83\% masuk kategori cukup terampil. Pada siklus III pertemuan 2 juga mengalami kenaikan nilai, nilai tertinggi sebesar 95,8 dan nilai terendah 66,7. Untuk lebih jelasnya dapat dilihat pada Tabel 7 berikut:

Tabel 7. Distribusi Frekuensi Nilai Keterampilan Bereksperimen pada siklus III

Pertemuan 2

\begin{tabular}{|c|c|c|c|c|}
\hline \multirow{2}{*}{$\begin{array}{c}\text { Interval } \\
\text { Nilai }\end{array}$} & \multirow[t]{2}{*}{$f$} & \multirow[t]{2}{*}{ Median } & \multicolumn{2}{|c|}{ (\%) } \\
\hline & & & Relatif & kumulatif \\
\hline $66,7-70,7$ & 4 & 68.7 & 16,67 & 20,83 \\
\hline $71,7-75,7$ & 4 & 73.7 & 16,67 & 33,33 \\
\hline $76,7-80,7$ & 5 & 78.7 & 20,83 & 54,17 \\
\hline $81,7-85,7$ & 7 & 83.7 & 29,17 & 83,33 \\
\hline $86,7-90,7$ & 3 & 88.7 & 12,5 & 95,83 \\
\hline $91,5-95,7$ & 1 & 93.7 & 4,17 & 100 \\
\hline Jumlah & 24 & & 100 & \\
\hline Nilai rata-rata & & & 79,3 & \\
\hline Ketuntasan Klasika & & & $83,33 \%$ & \\
\hline Nilai di bawah KKN & & & $16,67 \%$ & \\
\hline Nilai Tertinggi & & & 95,8 & \\
\hline Nilai Terendah & & & 66,7 & \\
\hline
\end{tabular}

Berdasarkan Tabel 7 dapat tdiketahui bahwa pada siklus III pertemuan 2 terdapat 20 siswa yang memperoleh nilai KKM yang telah ditentukan dan berarti masuk pada kategori terampil atau 83,33\%. Sebanyak 4 siswa atau 16,67\% masuk kategori cukup terampil. Dengan ini indikator kinerja sudah tercapai dan tindakan dapat dihentikan.

Peneliti sebelumnya telah melakukan kegiatan pratindakan kegiatan keterampilan bereksperimen pada siswa kelas V SD Negeri Reksosari 01 Kecamatan Suruh Kabupaten Semarang. Hasil yang didapatkan adalah tidak ada siswa yang mencapai nilai KKM atau 0\%. Nilai rata-rata yang diperoleh termasuk rendah yaitu hanya 41,3. Data tersebut menunjukkan bahwa keterampilan bereksperimen pada siswa kelas V SD Negeri Reksosari 01 Kecamatan Suruh Kabupaten Semarang masih rendah.

Setelah dilakukan kegiatan pembelajaran dengan menerapkan model Guided Inquiry pada siklus I, siklus II, dan siklus III, nilai keterampilan siswa mengalami peningkatan keterampilan bereksperimen. Model pembelajaran Guided Inquiry dapat meningkatkan beberapa aspek penilaian, karena dalam pembelajaran Guided Inquiry hal ini siswa tidak hanya fokus pada kognitif saja, melainkan semua aspek baik kognitif, afektif dan psikomotor dapat meningkat dengan baik.

Selain itu dengan model pembelajaran Guided Inquiry tidak diajarkan sekedar mennghapalkan suatu konsep namun diajarkan memahami konsep dengan baik. Hal ini sesuai dengan pendapat (Prehtiningsih, Ramli \& Nurmiyati, 2015) menjelaskan Guided Inquiry merupakan salah satu model pembelajaran yang tepat untuk mengajarkan siswa cara memahami konsep dengan baik, dan bukan sekedar 
menghapal konsep. Siswa diajarkan memahami konsep dengan cara terjun dan menggali langsung suatu konsep dengan salah satu jalannya adalah mengadakan suatu penelitian seperti seorang penemu. Hal ini sejalan dengan pendapat Bruner dalam Fathurrohman (2015: 104) tujuan dari model pembelajaran inkuiri adalah hendaknya seorang guru memberikan kesempatan kepada siswa-siswanya untuk menjadi seorang saintis, ahli, penemu atau problem solver. Diharapkan siswa juga mampu mengaplikasikan ilmu yang dipelajari melalui penemuan ini dengan baik dalam kehidupan sehari-hari.

\section{SIMPULAN}

Berdasarkan hasil penelitian tindakan kelas yang telah dilaksanakan selama tiga siklus dengan menggunkan penerapan model pembelajaran Guided Inquiry pada mata pelajaran IPA khususnya pada keterampilan bereksperimen pada siswa kelas $\mathrm{V}$ SD Negeri Reksosari 01 Kecamatan Suruh Kabupaten Semarang tahun ajaran 2017/2018 dapat disimpulkan bahwa melalui model pembelajaran Guided Inquiry dapat meningkatkan keterampilan bereksperimen siswa kelas V SD Negeri Reksosari 01 Kecamatan Suruh Kabupaten Semarang tahun ajaran 2017/2018.

Implikasi dari penelitian ini yaitu digunakan sebagai petunjuk bagi guru mengenai penerapan model pembelajaran Guided Inquiry untuk meningkatkan keterampilan bereksperimen dalam mata pelajaran IPA.

\section{DAFTAR PUSTAKA}

Fathurrohman, Muhammad. (2015). Model-model Pembelajaran Inovatif. Yogjakarta: Ar-Ruzz Media.

Hardiansah. (2017). Pembelajaran Guided Inquiry dalam Meningkatkan Keterampilan Proses Sains Calon Guru Pada Mata Kuliah Botani Phanerogamae. 9(1), 55-61. Majid, Abdul. (2013). Strategi Pembelajaran. Bandung: PT Remaja Rosdakarya.

Samatowa, U. (2009). Pembelajaran IPA di Sekolah Dasar. Jakarta: PT Indeks.

Wenning, Carl J. (2011). The Levels of Inquiry Model of Science Teaching. Jurnal Physic Teacher Education Online. 2011;6(2) 9-16.

Zeidan, Afif Hafez. Jayosi, Majdi Rashed (2015). Science Process Skills and Attitudes toward Science among Palestinian Secondary School Students. World Journal of Education. 2015; 13-24. 